\title{
Y-box binding protein-1 regulates cell proliferation and is associated with clinical outcomes of osteosarcoma
}

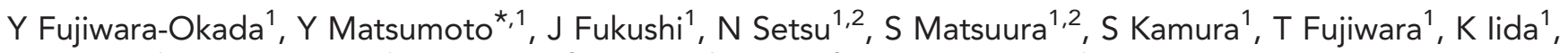 \\ M Hatano ${ }^{1}$, A Nabeshima $^{1}, \mathrm{H} \mathrm{Yamada}^{3}, \mathrm{M} \mathrm{Ono}^{4}, \mathrm{Y} \mathrm{Oda}^{2}$ and $\mathrm{Y}$ Iwamoto ${ }^{1}$ \\ ${ }^{1}$ Department of Orthopaedic Surgery, Kyushu University, Fukuoka, Japan; ${ }^{2}$ Department of Anatomic Pathology, Kyushu University, \\ Fukuoka, Japan; ${ }^{3}$ Department of the Division of Host Defense, Kyushu University, Fukuoka, Japan and ${ }^{4}$ Department of \\ Pharmaceutical Oncology, Kyushu University, Fukuoka, Japan
}

Background: Prognosis of osteosarcoma (OS) with distant metastasis and local recurrence is still poor. Y-box binding protein-1 (YB-1) is a multifunctional protein that can act as a regulator of transcription and translation and its high expression of YB-1 protein was observed in OS, however, the role of YB-1 in OS remains unclear.

Methods: Y-box binding protein-1 expression in OS cells was inhibited by specific small interfering RNAs to YB-1 (si-YB-1). The effects of si-YB-1 in cell proliferation and cell cycle transition in OS cells were analysed in vitro and in vivo. The association of nuclear expression of YB-1 and clinical prognosis was also investigated by immunohistochemistry.

Results: Proliferation of OS cell was suppressed by si-YB-1 in vivo and in vitro. The expression of cyclin D1 and cyclin A were also decreased by si-YB-1. In addition, si-YB-1 induced G1/S arrest with decreased cyclin D1 and cyclin A in OS cell lines. Direct binding of YB-1 in OS cell lines was also observed. Finally, the nuclear expression of YB-1 was significantly related to the poorer overall survival in OS patients.

Conclusion: Y-box binding protein-1 would regulate cell cycle progression at G1/S and tumour growth in human OS cells in vitro and in vivo. Nuclear expression of YB-1 was closely associated with the prognosis of OS, thus, YB-1 simultaneously could be a potent molecular target and prognostic biomarker for OS.

Osteosarcoma (OS) is the most common malignant bone tumour in patients under 20 years old. The prognosis of OS in younger patients has improved markedly, mainly due to the introduction of adjuvant and neo-adjuvant chemotherapy (Iwamoto et al, 2009). However, the prognosis of advanced cases with distant metastasis and local recurrence is still poor, even with extensive chemotherapy. Thus, new treatment agents and other forms of therapy are needed.

The Y-box binding protein-1 (YB-1) is a member of the DNAbinding protein family (Kohno et al, 2003) that has essential roles in transcription (Ladomery, 1997; Matsumoto and Wolffe, 1998), regulation of translation, DNA repair (Das et al, 2007), and other biological processes in both the nucleus and cytoplasm (Law et al, 2006). Y-box binding protein-1 knockout mice exhibit a marked decrease in cell proliferation rates and are embryonic lethal ( $\mathrm{Lu}$ et al, 2005; Uchiumi et al, 2006), indicating the involvement of YB-1 in cell proliferation. High YB-1 expression levels have been observed in a variety of cancers, including primary breast cancer (Bargou et al, 1997), prostate cancer (Giménez-Bonafé et al, 2004), primary melanoma (Schittek et al, 2007), and colorectal cancer (Shibao et al, 1999). Importantly, YB-1 activation increases expression of the ATP-binding cassette (ABC) transporter 
gene-encoding ABCB1 (P-glycoprotein (P-gp)), which enhances the multi-drug resistance of malignant tumours and cultured human cancer cells in response to genotoxic stimuli (Asakuno et al, 1994; Ohga et al, 1996). In particular, YB-1 is translocated into the nucleus in invasive and metastatic melanoma cells. Furthermore, YB-1 downregulation reduced the migration and invasion of melanoma cells in a monolayer and a three-dimensional skin model, which was accompanied by the downregulation of genes involved in migration/invasion, such as MMP2 (Schittek et al, 2007). In addition, transgenic expression of YB-1 causes the development of breast carcinomas (Bergmann et al, 2005), whereas YB-1 siRNA knockdown decreases the proliferation of human breast cancer cells (Lee et al, 2008), prostate cancer cells (Shiota et al, 2008), and multiple myeloma cells (Chatterjee et al, 2008). Together, these findings strongly suggest that YB-1 is an oncogene and is involved in the proliferation and malignant phenotype of tumours.

We previously reported that nuclear localisation of YB-1 protein was associated with the expression of P-gp (Oda et al, 1998). As $\mathrm{P}$-gp is associated with multi-drug resistance to a wide range of anticancer agents in human malignant tumours, it is a useful prognostic marker for assessing therapeutic efficacy in several cancers, especially in breast cancers (Trock et al, 1997). However, a meta-analysis study of OS did not clearly support a correlation between P-gp expression level and histologic response to chemotherapy or prognosis (Pakos and Ioannidis, 2003). Therefore, the role of YB-1 in OS, particularly in the clinical outcome in the patients with OS, is unclear. Alterations in the normal cell cycle lead to abnormal cell proliferation and tumour development. The cell cycle control is predominantly controlled at the G1/S transition and the induction of positive factors and deregulation of negative factors that regulate cell cycle progression may cause an imbalance in this transition, leading to malignant transformation (Weinberg, 1989). Regarding the role of YB-1 in the cell cycle, it was reported that nuclear YB-1 expression is induced during the G1-S transition of the cell cycle (Jurchott et al, 2003). Furthermore, alterations in the G1/S transition have been identified in different types of tumours, including OS (Benassi et al, 1997), suggesting that YB-1 could be involved in the G1/S transition and proliferation of OS cells.

Here, we analysed the roles of YB-1 in the proliferation of OS cells by siRNA-mediated downregulation of YB-1 expression. Reduced expression of YB-1 in OS cells caused decreased proliferation and altered the cell cycle progression and the expression profile of cell cycle-related genes. These in vitro results were further confirmed by in vivo data from xenografts model of OS in nude mice. Finally, we showed that nuclear expression of YB-1 was associated with poor prognosis in OS patients, indicating that $\mathrm{YB}-1$ is a prognostic biomarker and a promising molecular target for treatment of OS.

\section{MATERIALS AND METHODS}

Cell cultures. Human OS cell lines, MG63, MNNG, and SaOS2 cells, were obtained from the American Type Culture Collection (Rockville, MD, USA). These cells were cultured in Dulbecco's modified Eagle's medium (DMEM; Invitrogen Corp., Carlsbad, CA, USA) supplemented with $10 \%$ heat-inactivated foetal bovine serum (HyClone Laboratories, Inc., Logan, UT, USA) and penicillin $\left(100 \mathrm{U} \mathrm{ml}^{-1}\right)+$ streptomycin $\left(100 \mu \mathrm{g} \mathrm{ml}^{-1}\right)$ at $37^{\circ} \mathrm{C}$ in a humidified $5 \% \mathrm{CO}_{2}$ atmosphere.

Knockdown analysis using small interfering RNAs. The following double-stranded 25-bp RNA oligonucleotides were commercially generated: YB-1siRNA\#1 (small interfering RNAs to YB-1 (si-YB-1)\#1), 5'-UUUGCUGGUAAUUGCGUGGAGGACC-3' (sense) and 5'-GGUCCUCCACGCAAUUACCAGCAAA-3' (antisense); YB-1siRNA\#2 (si-YB-1\#2), 5'-AAAGCAAGCACUUUAG GUCUUCAGC-3' (sense) and $5^{\prime}$-GCUGAAGACCUAAAGUG CUUGCUUU-3' (antisense; Shiota et al, 2008; Invitrogen Corp.); cyclin A siRNA (si-cyclin A), 5'-GAUAUACCCUGGAAAGU CUTT-3' (sense), and 5'-AGACUUUCCAGGGUAUAUCCA- ${ }^{\prime}$ (antisense; Invitrogen Corp.). Cyclin D1 siRNA (si-cyclin D1) strand A: 5'-UCGUCGCCACCUGGAUGCU- $3^{\prime}$, strand B: 5'-AGUGGAACCUGGCCGCAAU-3', and strand C: $5^{\prime}$-AACAG AUCAUCCGCAAACA- $3^{\prime}$ were purchased from Santa Cruz Biotechnology (Santa Cruz, CA, USA). Negative control cocktail (si-Ctr; S6C-0126) was also purchased from Cosmobio Co., Ltd. (Tokyo, Japan). MG63, MNNG, or SaOS2 cells were transfected with siRNAs as previously described (Shiota et al, 2008). Cells were transiently transfected with $50 \mathrm{pmol} \mathrm{ml}^{-1}$ of each siRNA using Lipofectamine 2000 and Opti-MEM medium (Invitrogen Corp.), according to the manufacturer's recommendation.

Cell proliferation assay. MG63, MNNG, and SaOS2 cells $\left(5.0 \times 10^{4}\right)$ were seeded in six-well plates and transfected with siRNA as described above. Twelve hours after transfection was set as $0 \mathrm{~h}$. The cells were harvested with trypsin and counted at 0,24 , 48,72 , and $96 \mathrm{~h}$ with a $\mathrm{Z} 1$ coulter, particle counter (Beckman Coulter, Inc., Brea, CA, USA).

Cell cycle analysis by flow cytometry. MG63, MNNG, or SaOS2 cells $\left(1.5 \times 10^{5}\right)$ were seeded in $60 \mathrm{~mm}$ dishes, transfected with scramble si-Ctr, si-YB-1, si-cyclin D1 or si-cyclin A, and cultured for 48 or $72 \mathrm{~h}$. The cells were harvested with trypsin, washed with phosphate-buffered saline (PBS), and fixed in ice-cold 70\% ethanol for $1 \mathrm{~h}$. The cells were resuspended in PBS with $0.1 \%$ bovine serum albumin, incubated with RNase $\left(50 \mu \mathrm{g} \mathrm{ml}^{-1}\right)$, and stained with propidium iodide $\left(50 \mu \mathrm{g} \mathrm{ml}^{-1}\right)$ for $10 \mathrm{~min}$. The cells were run on a FACS Calibur flow cytometer (BD Biosciences, Franklin Lakes, NJ, USA). The data were analysed using CELL Quest software (BD Biosciences).

Antibodies. Antibody against YB-1 was kindly provided by Dr Ono (Kyushu University, Fukuoka, Japan). Antibodies against cyclin A, cyclin D1, cyclin E, p21, and p27 were purchased from Santa Cruz Biotechnology. Antibody against poly ADP-ribose polymerase (PARP) was purchased from Promega (Madison, WI, USA).

Western blot analysis. Western blot analysis was performed as described previously (Kamura et al, 2010). Cells were washed twice with ice-cold PBS, scraped, collected in a microcentrifuge tube, and then centrifuged. The cells were lysed by adding lysis buffer (CelLytic M mammalian cell lysis/extraction reagent, SigmaAldrich Corp., St Louis, MO, USA), with a protease inhibitor cocktail (Complete Mini, EDTA-free and PhosSTOP; F-HoffmanLa Roche AG, Basel, Switzerland). After incubating the cells for $10 \mathrm{~min}$ on ice, the cellular debris was pelleted by centrifuging for $10 \mathrm{~min}$ at $12000 \mathrm{~g}$, and the resulting protein-containing supernatant was transferred into another tube. The protein quantity in the lysate was determined using a Bradford protein assay (Bio-Rad, Hercules, CA, USA). The samples were boiled for $5 \mathrm{~min}$ with NuPAG LDS sample buffer (Invitrogen Corp.) and 2-mercaptoethanol (Wako, Osaka, Japan). The samples were applied and fractionated on pre-cast $4-12 \%$ gradient MOPS polyacrylamide gels (NuPAGE Bis-Tris Gels, Invitrogen Corp.) and were transferred onto nitrocellulose membranes. The membranes were pre-treated with tris-buffered saline (TBS) containing 5\% non-fat dry milk for $1 \mathrm{~h}$ at room temperature and then incubated with the appropriate primary antibodies at $4{ }^{\circ} \mathrm{C}$ overnight. After washing the membranes, horseradish peroxidase-conjugated secondary antibodies (Santa Cruz Biotechnology) were added and the membranes were incubated at room temperature for $1 \mathrm{~h}$. After washing, the immunoreactivity of the blots was detected using an 
ECL Plus Western Blotting Detection System (GE Healthcare, Tokyo, Japan).

RNA isolation and quantitative RT-PCR. Real-time RT-PCR was performed as described previously (Fujiwara et al, 2011). Total RNA was extracted from each cell pellet using the RNeasy Mini Kit (Qiagen GmbH, Hilden, Germany). First-strand cDNA was generated from total RNA using a First-Strand cDNA Synthesis Kit (Invitrogen Corp.) with random hexamer primers. Real-time quantitative RT-PCR was performed to compare the level of expression of each mRNA using the LightCycler system (HoffmanLa Roche AG) with the SYBR Green I reagent (Takara Bio, Inc., Tokyo, Japan). Expression levels of YB-1, cyclin D1, and cyclin A were examined using specific primers (Supplementary Table 1).

Chromatin immunoprecipitation (ChIP). To collect chromatin for immunoprecipitation, MG63 and MNNG cells were grown to near confluence $\left(1 \times 10^{7}\right.$ cells $)$. The ChIP assay was performed with a ChIP Assay kit (Upstate Biotechnology, Lake Placid, NY, USA) according to the manufacturer's instructions. MG63 and MNNG cells were plated at a density of $3 \times 10^{6}$ on $10 \mathrm{~cm}$ dishes and cultured. MG63 and MNNG cells were fixed with $4 \%$ formaldehyde and sonicated. After dilution to $2 \mathrm{ml}$ with ChIP dilution buffer and two precleanings with protein A-agarose beads, half of the sample was incubated with anti-YB-1 antibodies, and the other half was treated with normal rabbit IgG (Santa Cruz Biotechnology) as the negative control. Before the second precleaning, $10 \mu \mathrm{l}$ of sample was saved as the input DNA sample. The following primers from the human cyclin D1 promoter sequences were used in PCR: $5^{\prime}$-AATGCACCAAAGAGACA GAACC- $3^{\prime}$ (forward) and 5'-AAGACCACCGAAGGTTCC TAATTG- $3^{\prime}$ (reverse), which amplified between -1246 bp and $961 \mathrm{bp}$ and included the YB-1 binding motifs, and $5^{\prime}$-TGCT TTCTCTGCGCTTCTTG-3' (forward) and $5^{\prime}$-TGGTTAGCG AGCGTAAAGAGC-3' (reverse), which amplified between $-2279 \mathrm{bp}$ and $-2073 \mathrm{bp}$ for the negative control. PCR products were amplified for 33 cycles.
Atelocollagen and tumour therapy. MNNG cells were subcutaneously injected $\left(1.0 \times 10^{7}\right.$ cells per site $)$ with $0.2 \mathrm{ml}$ of $10 \%$ serum DMEM medium through a 23-gauge needle into the lower flank of 5 -week-old athymic nude mice obtained from Charles River Japan (Fukuoka, Japan). When the tumours reached a volume of $65 \mathrm{~mm}^{3}$ (day 0 ), the mice were randomly treated with si-YB-1 or scramble si-Ctr with atelocollagen (Koken Co., Ltd., Tokyo, Japan) as described previously (Honma et al, 2001; Minakuchi et al, 2004; Takeshita et al, 2005; Hanai et al, 2006; Takigami et al, 2011). The final concentration of atelocollagen was $0.5 \%$. The siRNA concentration was $2.5 \mu \mathrm{g}$ per tumour equivalent to that used in the atelocollagen experiments. Each siRNA with atelocollagen was injected into the tumours 7 and 14 days after the first injection. Tumour diameters were measured at regular intervals with a caliper for 3 weeks, and the tumour volume in $\mathrm{mm}^{3}$ was calculated

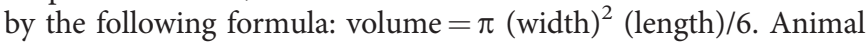
experiments in this study were performed in compliance with the guidelines of the Institute for Laboratory Animal Research, Kyushu University.

Clinical samples. The tissues were collected during primary tumour biopsy at diagnosis between 1985 and 2009 at the Department of Anatomical Pathology, Pathological Sciences, Graduate School of Medical Science, Kyushu University, Fukuoka, Japan. In each case, a diagnosis of OS was made on the basis of histologic features. Of these 43 cases, 3 were excluded, because of lack of availability of adequate tissue; thus, 40 patients were included in this study. All 40 patients had primary OS, and all 40 patients underwent treatment with systemic, multiple-agent chemotherapy in combination with surgery and/or heavy particle radiotherapy. The Institutional Review Board at Kyushu University approved the use of human specimens for this study.

Immunohistochemistry. We examined formalin-fixed and paraffin-embedded samples from 40 cases of OS. All pathological samples were from open biopsy specimens obtained before chemotherapy at Kyushu University Hospital. The preoperative chemotherapy regimen and histological response to chemotherapy
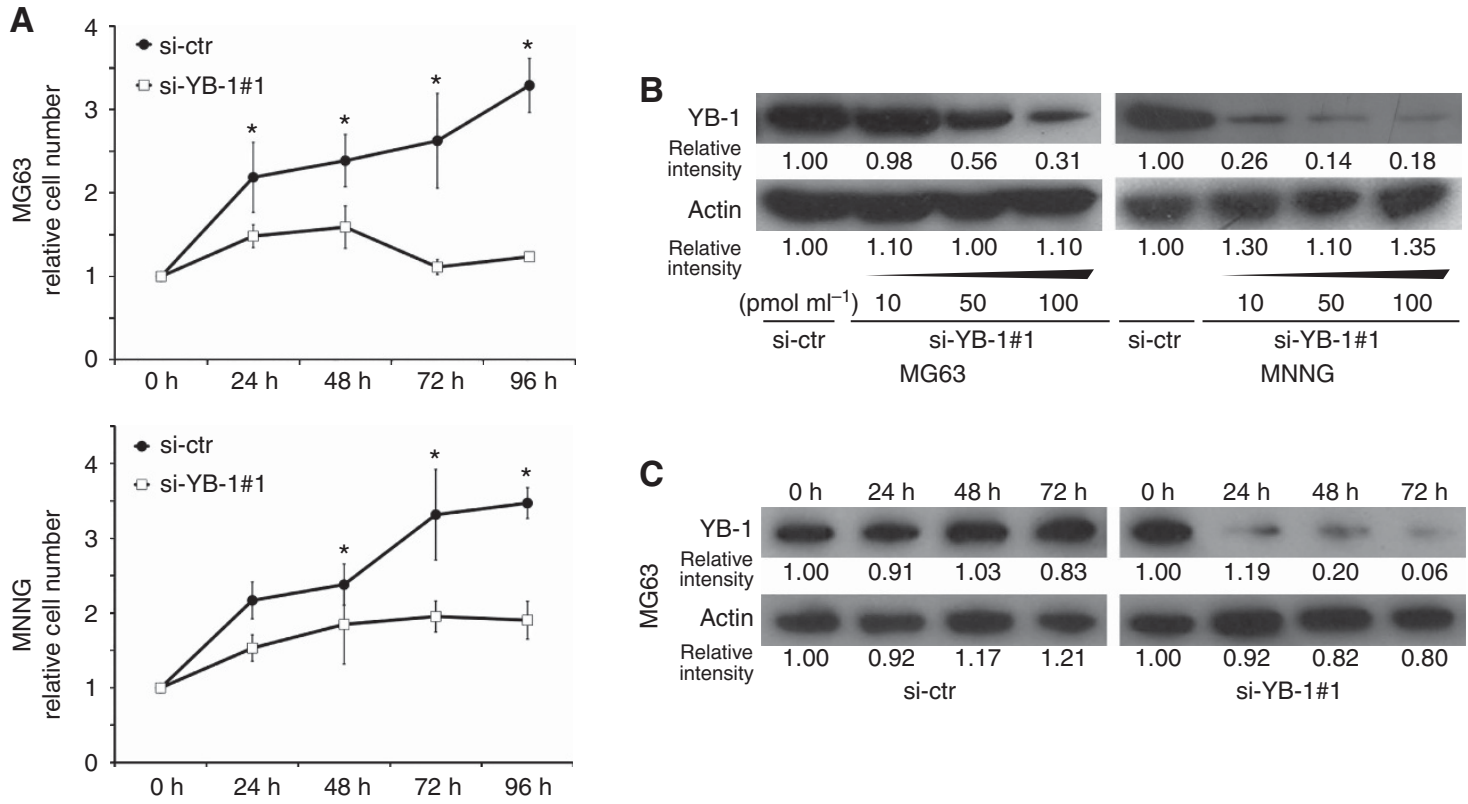

Figure 1. Silencing the YB-1 gene reduces cell proliferation and downregulates YB-1 expression at the protein level in OS cell lines. (A) Growth curve of MG63 and MNNG cells transfected with si-Ctr or si-YB-1\#1 monitored up to 96-h post-transfection. Experiments were performed in triplicate, and data are expressed as the mean \pm s.d. ${ }^{*} P<0.05$. (B and $\mathbf{C}$ ) Downregulation of YB-1 protein in MG63 and MNNG cells as shown by western blotting after silencing of the YB-1 gene. Actin was used for internal normalisation. Relative intensity is shown under each blot. si-YB-1\#1 treatment resulted in downregulation of YB-1 protein expression in a dose-dependent (B) and time-dependent (C) manner. 

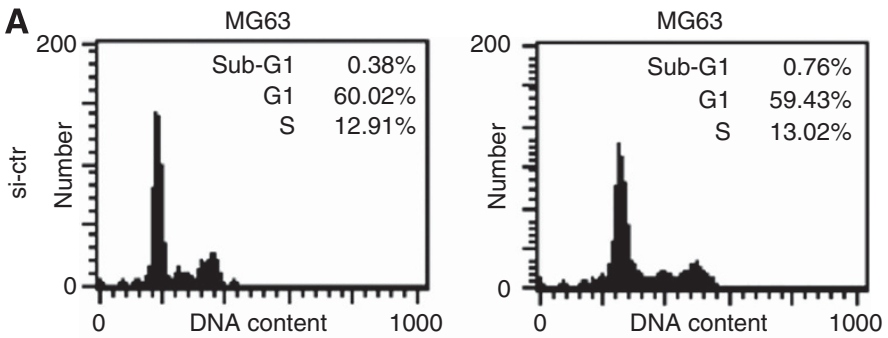

$\mathbf{B}$
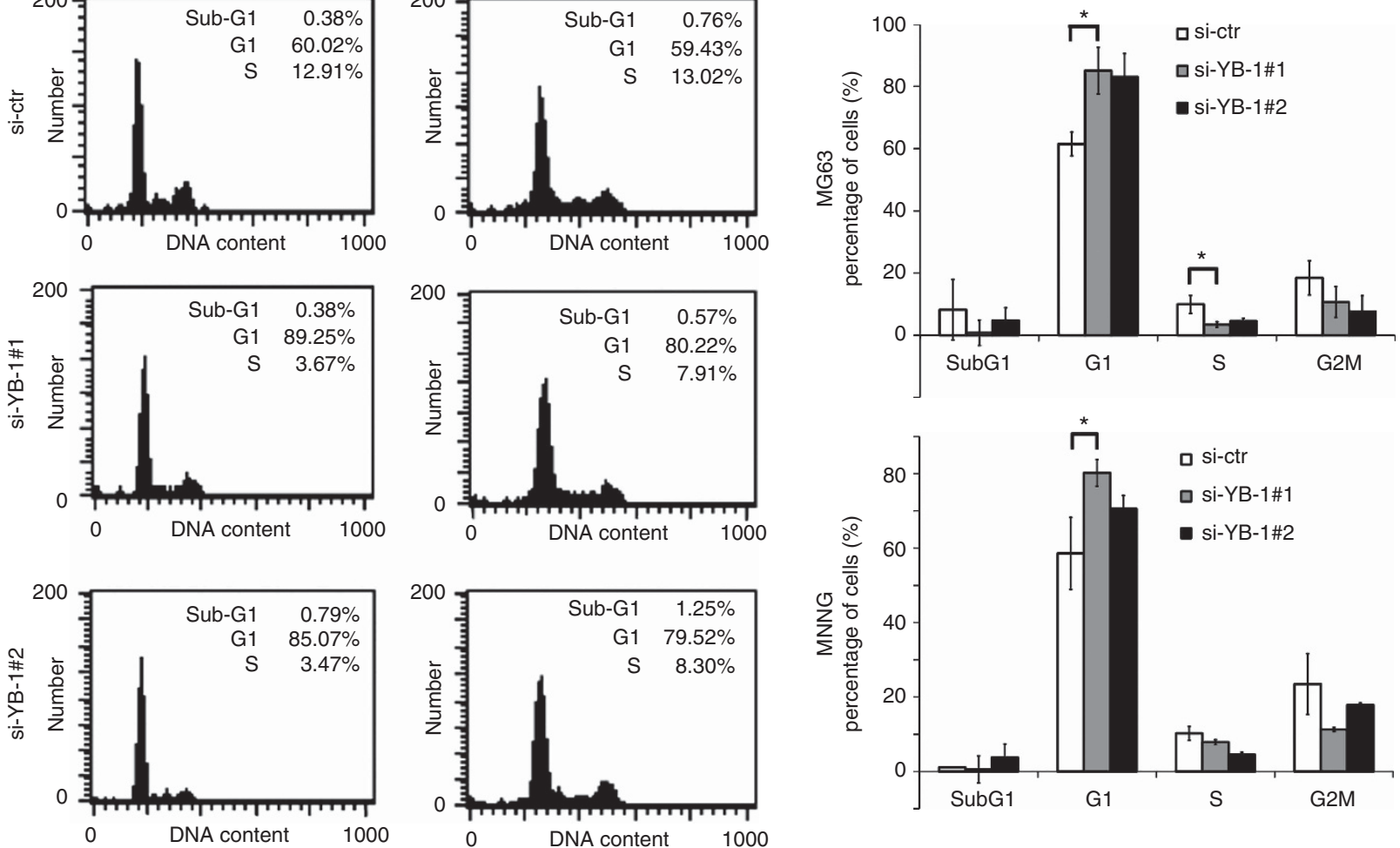

Figure 2. Effects of si-YB-1 on cell cycle progression in human OS cell lines. (A) Representative cell cycle profile of MG63 and MNNG cells transfected with si-Ctr, si-YB-1\#1, or si-YB-1\#2. Cells were treated with siRNA for $72 \mathrm{~h}$, and then detached from the substratum by limited trypsin digestion, and a single-cell suspension was used for propidium iodide staining. DNA content in single cells was measured by flow cytometry. (B) Increased G1/G0 and decreased S phase DNA content by YB-1 knockdown in MG63 and MNNG cell lines. Experiments were performed in triplicate, and data are expressed as the mean \pm s.d. ${ }^{*} P<0.05$.

were available for these patients, as described above. The samples were sliced in $4 \mu \mathrm{m}$ sections and deparaffinised using xylene. The sections were then pre-treated with citrate buffer $(0.01 \mathrm{~m}$ citric acid, $\mathrm{pH}$ 6.0) for $15 \mathrm{~min}$ at $100^{\circ} \mathrm{C}$ in a microwave oven. Endogenous peroxidase was blocked by methanol containing $0.3 \%$ hydrogen peroxidase for $5 \mathrm{~min}$.

The sections were incubated with one of following antibodies: rabbit polyclonal anti-YB-1 antibody $(1: 300)$, mouse monoclonal anti-cyclin D1 antibody $(1: 25)$, rabbit polyclonal anti-cyclin A antibody $(1: 100)$, or mouse monoclonal anti-MIB-1 antibody (1:100; Dako A/S, Glostrup, Denmark). All primary antibodies were incubated at $4{ }^{\circ} \mathrm{C}$ overnight. After washing the sections, staining was visualised using the Envision plus system (Dako A/S), followed by counterstaining with haematoxylin, and mounted. Negative controls omitting the primary antibody were included.

YB-1-negative or -positive cells were scored based on nuclear expression of YB-1 in tumour cells. As in previous studies (Molendini et al, 1998; Huang et al, 2012), cyclin D1 was defined as overexpressed when $\geqslant 10 \%$ of tumour cells displayed moderate-tostrong nuclear staining, whereas cyclin A was considered overexpressed when $\geqslant 40 \%$ of tumour cells showed moderate-to-strong nuclear staining. For each sample, an area encompassing 1000 tumour cells was scored under high power magnification $(\times 400)$.

Statistical analyses. Univariate and multivariate survival analyses were performed using the log-rank test or the Cox proportional hazards regression model. The survival curve was estimated using the Kaplan-Meier method. For demonstration of associations between YB-1 nuclear expression and cyclin D1 or cyclin A expression, Fisher's exact test was used to evaluate the association between two dichotomous variables (the nuclear expression of
YB-1 and $\geqslant 10 \%$ of cyclin D1-positive cells or $\geqslant 40 \%$ of cyclin A-positive cells). A $P$-value of $<0.05$ was considered statistically significant. The Mann-Whitney $U$-test was used for two-group comparisons. All data analysis was performed using a statistical software package (SAS Institute, Inc., Cary, NC, USA).

\section{RESULTS}

Effect of siRNA-based knockdown of YB-1 on cell proliferation in OS cell lines. To investigate the possible role of YB-1 in proliferation of human OS cell lines, we silenced YB-1 with siRNA (si-YB-1\#1) in MG-63 and MNNG cells, and evaluated cell growth for $96 \mathrm{~h}$. si-YB-1\#1 treatment inhibited the growth of both OS cell lines by 37.4 on $55.9 \%$ (Figure 1A) and inhibited cell proliferation and YB-1 protein expression of human OS SaOS2 cell lines (Supplementary Figure 1). We have same results with alternative si-YB-1\#2 (Supplementary Figure 2). We confirmed that siYB-1 treatment reduced the expression of $\mathrm{YB}-1$ in a dose-dependent and time-dependent manner (Figures $1 \mathrm{~B}$ and $\mathrm{C}$ ). These results indicate that, in agreement with results in other malignant tumour cell lines, such as breast and lung (Basaki et al, 2010), knockdown of YB-1 by si-YB-1 inhibited the proliferation of three OS cell lines.

Downregulation of YB-1 inhibits the G1/S transition in OS cells. To understand the implications of the si-YB-induced inhibition of OS cell proliferation, OS cell lines were treated with siYB-1\#1 and assayed for DNA content at 72-h post-transfection by flow cytometry. Silencing YB-1 expression in OS cell lines significantly increased the proportion of cells in G1 phase, from $61.51 \pm 3.83$ to $85.07 \pm 7.51$ in MG63 cells and 58.6 \pm 9.65 to 
A

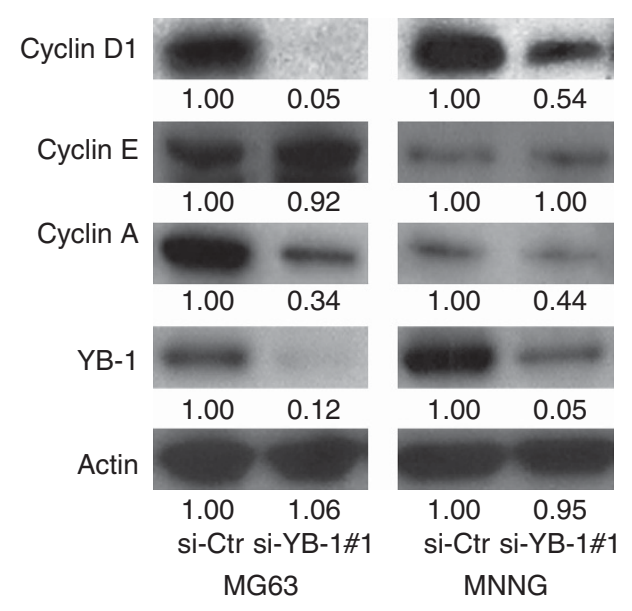

C $_{\text {Promoter region }}$ (-1246/-961)

\section{Negative control} (-2279/-2072)

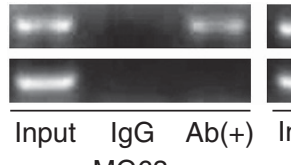
MG63

D
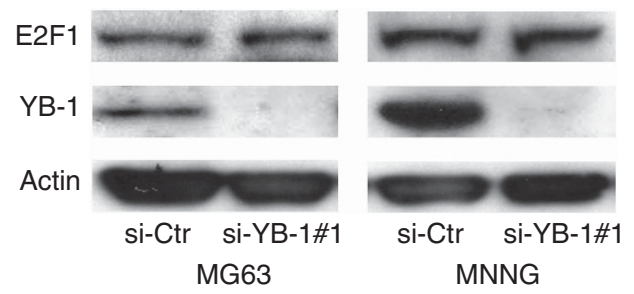
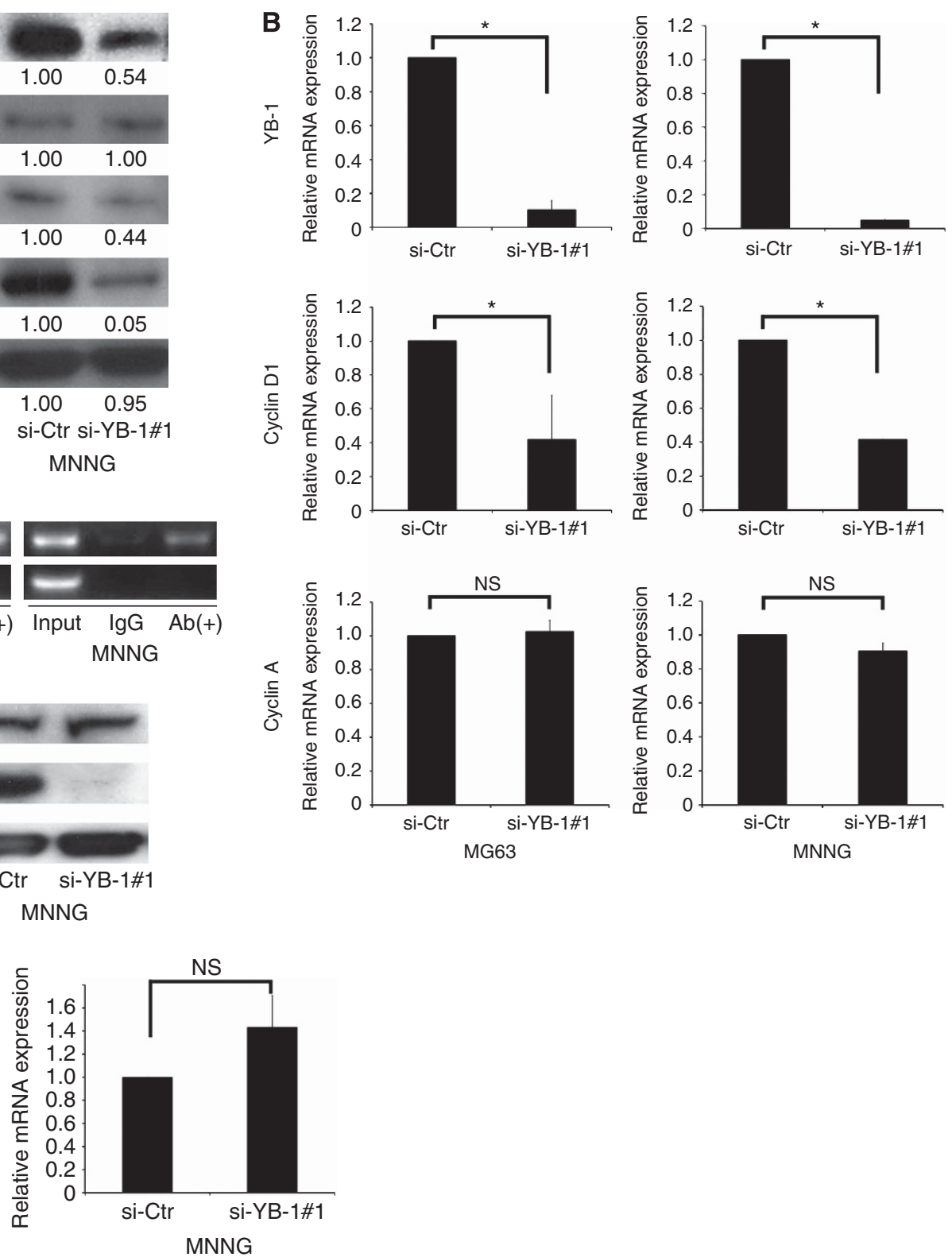

Figure 3. Silencing the YB-1 gene in OS cells modulates cell cycle-related genes. (A) Effect of YB-1 knockdown on expression of cyclin D1, cyclin $\mathrm{E}$, cyclin A, YB-1, and actin protein was analysed by immunoblotting. Cells were incubated with $50 \mathrm{nmoll} \mathrm{I}^{-1}$ of si-Ctr or si-YB-1\#1 for $48 \mathrm{~h}$, and lysates were prepared. (B) Effect of YB-1 knockdown on cyclin D1 and cyclin A mRNA expression. Experiments were performed in triplicate, and data are expressed as the mean \pm s.d. ${ }^{*} P<0.05$. (C) Chromatin immunoprecipitation of cyclin D1 gene promoters using YB-1 antibody. Chromatin from MG63 and MNNG cell lines were cross-linked to fix bound proteins to the DNA. Cells were lysed and the chromatin was incubated with a YB-1 antibody to immunoprecipitate promoters bound by YB-1. Polymerase chain reaction was then performed to amplify promoter fragments to known to YB-1 bound. Input=DNA before immunoprecipitation; IgG = ChIP with the IgG-negative control antibody; Ab=YB-1 antibody. Figure shows typical results obtained from at least three independent experiments. (D) Effect of silencing of the YB-1 gene on expression of E2F1, and YB-1 protein was analysed by immunoblotting. Actin was used for internal normalisation. Effect of YB-1 knockdown on E2F1 mRNA expression. Experiments were performed in triplicate, and data are expressed as the mean \pm s.d. NS=nonsignificant.

$80.22 \pm 3.58$ in MNNG cells, compared with cells treated with a scrambled siRNA $(P<0.01$; Figure $2 \mathrm{~B})$. Representative cell cycle profiles are shown (Figure $2 \mathrm{~A})$. This effect of si-YB-1\#1 was also confirmed in SaOS2 cells (Supplementary Figure 3). In addition, YB-1 knockdown caused a marked decrease in the proportion of cells in S phase in both cell lines (MG63: $12.9 \%$ to $4.4 \%$, MNNG: $12.2 \%$ to $6.78 \% ; P<0.01$; Figure $2 \mathrm{~B}$ ). However, the proportion of cells in sub-G1 phase remained the same (Figure 2B), suggesting that the reduction in cell number was not due to apoptosis. Moreover, although treatment of OS cell lines with si-YB-1 downregulated the expression of YB-1, cleaved PARP levels (Simbulan-Rosenthal et al, 1998) did not increase (data not shown). These results show that loss of YB-1 results in inhibition of the G1/S transition, but does not induce apoptotic cell death. Y-box binding protein-1 interacts with the p53 tumour-suppressor protein and inhibits p53-mediated apoptosis but does not interfere with p53-induced transactivation of p21 (Homer et al, 2005). The OS cell lines used in this study (MG63, MNNG, and SaOS2 cells) have mutations or deletions in p53 (Chandar et al, 1992; Ganjavi et al, 2006). Therefore, loss of normal p53 function could explain 

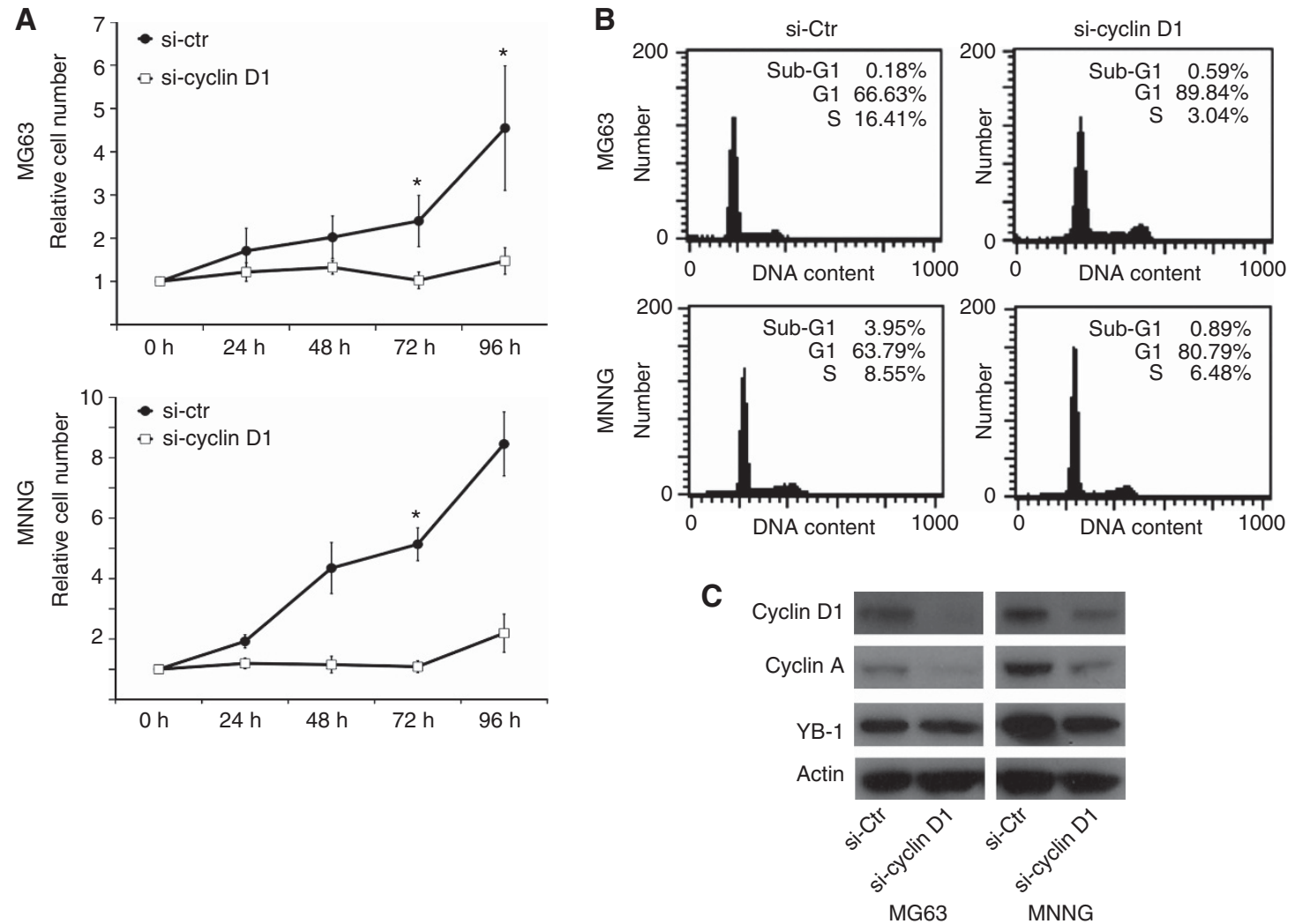

Figure 4. Effects of si-cyclin D1 on cell proliferation and cell cycle progression in human OS cell lines. (A) Growth curve of MG63 and MNNG cells transfected with si-Ctr or si-cyclin D1 monitored up to $96 \mathrm{~h}$ post-transfection. Experiments were performed in triplicate, and data are expressed as the mean \pm s.d. ${ }^{\star} P<0.05$. (B) Representative cell cycle profile of MG63 and MNNG cells transfected with si-Ctr or si-cyclin D1. (C) Effect of silencing of the cyclin D1 gene on expression of cyclin D1, cyclin A, and YB-1 protein was analysed by immunoblotting. Actin was used for internal normalisation.

why a reduction in YB-1 inhibited the G1/S transition, but did not induce apoptotic cell death in OS cell lines.

YB-1 knockdown modulates expression of cell cycle-related genes in OS cells. Next, we investigated the effects of YB-1 knockdown on the expression profiles of genes known to regulate the cell cycle. We first focused on cyclin D1, since previous reports have shown that cyclin D1 is specifically downregulated by YB-1 knockdown in human multiple myeloma cells (Chatterjee et al, 2008) and, recently, YB-1 has been reported to bind to the promoter of cyclin D1 (Lasham et al, 2012). Consistent with this, si-YB-1\#1 treatment decreased the expression of cyclin D1 by $5 \%$ to $54 \%$ (median $25.6 \%$ ) in all OS cell lines tested, as shown by immunoblotting (Figure 3A). We have same results with alternative si-YB-1\#2 (Supplementary Figure 4). Interestingly, we also observed that expression of cyclin A protein, which regulates both the G1/S and G2/M transitions, was downregulated by $34 \%$ to $44 \%$ on si-YB-1\# 1 treatment. Other cell cycle-related genes, such as cyclin E (Figure 3A), cyclin-dependent kinases (CDK)1, and CDK4 (data not shown), were unaffected by YB-1 knockdown.

As YB-1 is a known transcription factor (Kohno et al, 2003), we next examined whether expression of cyclin D1 and cyclin A mRNA was altered by decreased expression of YB-1. Cyclin D1 expression was significantly decreased by treatment with si-YB-1, but not with the control scrambled siRNA. In contrast, cyclin A expression was not affected by siRNA treatment (Figure 3B). These results suggest that cyclin $\mathrm{D} 1$ is a primary target of YB-1 during the G1/S transition in OS cells. To confirm this, we then carried out ChIP-PCR to determine whether YB-1 bound to the promoter of cyclin D1. As shown in Figure 3C, endogenous YB-1 in OS cells clearly bind to the promoter of cyclin D1. Recently, it has been reported that $\mathrm{YB}-1$ directly bind to $\mathrm{E} 2 \mathrm{~F} 1$ promoters in breast cancer cell lines and the si-YB-1 treatment inhibit E2F1 expression (Lasham et al, 2012). As cyclin D1 is well-defined target genes of E2F1 (Lasham et al, 2012), reduction of cyclin D1 expression by siYB-1 in OS cells could be the reflection of si-YB-1-induced reduction of E2F1. However, we confirmed that si-YB-1\#1 treatment did not affect the mRNA and protein expression of E2F1 in OS cells and therefore suggested that YB-1 would not be a potential transcriptional regulator of E2F1 in OS cell. (Figure 3D)

Next, we inhibited cyclin D1 expression in OS cells and found that cyclin D1 knockdown in OS cells resulted in decreased proliferation and a delayed G1/S transition, as was observed from YB-1 knockdown (Figure 4A and B). Furthermore, reduction of cyclin D1 expression in OS cells inhibited cyclin A protein expression without affecting the expression of YB-1 (Figure 4C). Together, these results show that altered cyclin A expression following YB-1 knockdown in OS cells is secondary to reduction of cyclin D1.

We were also interested in the role of cyclin A in the G1/S transition in OS cells, as this seems to differ between cell lines (Jurchott et al, 2003). To test this, expression of cyclin A in OS cells was inhibited by treatment with cyclin A siRNA (si-cyclin A). Remarkably, si-cyclin A blocked cell proliferation and the G1/S transition in all OS cell lines tested (Figure 5A and B), indicating a critical role for cyclin $A$ in the G1/S transition in OS cells. However, si-cyclin A did not affect the expression of cyclin D1 and YB-1 (Figure 5C). To determine whether cyclin D1 is directly involved in inhibition of cell proliferation by YB-1 knockdown, we performed double transfection experiments of si-YB-1\#1 and 

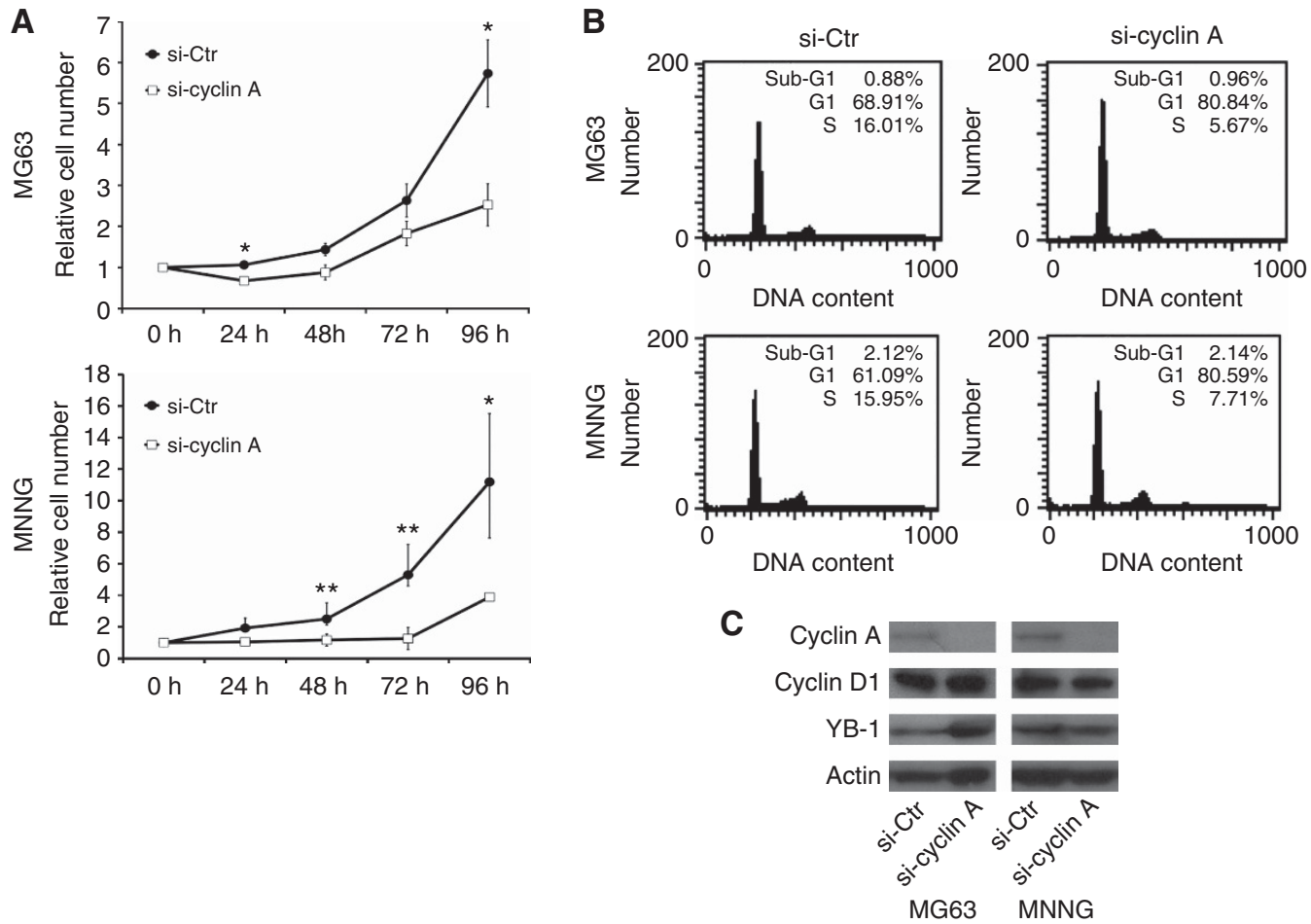

Figure 5. Effects of si-cyclin A on cell proliferation and cell cycle progression in human OS cell lines. (A) Growth curve of MG63 and MNNG cells transfected with si-Ctr or si-cyclin A monitored up to $96 \mathrm{~h}$ post-transfection. Experiments were performed in triplicate, and data are expressed as the mean \pm s.d. ${ }^{\star} P<0.05,{ }^{\star \star} P<0.001$. (B) Representative cell cycle profile of MG63 and MNNG cells transfected with si-Ctr or si-cyclin A. (C) Effect of silencing the cyclin A gene on expression of cyclin A, cyclin D1, and YB-1 protein was analysed by immunoblotting. Actin was used for internal normalisation.

A

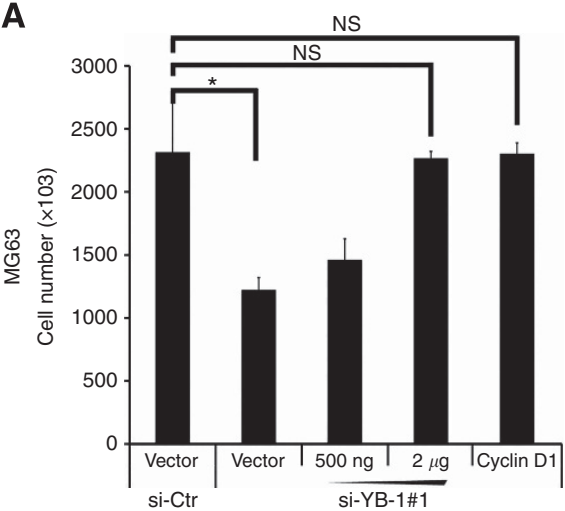

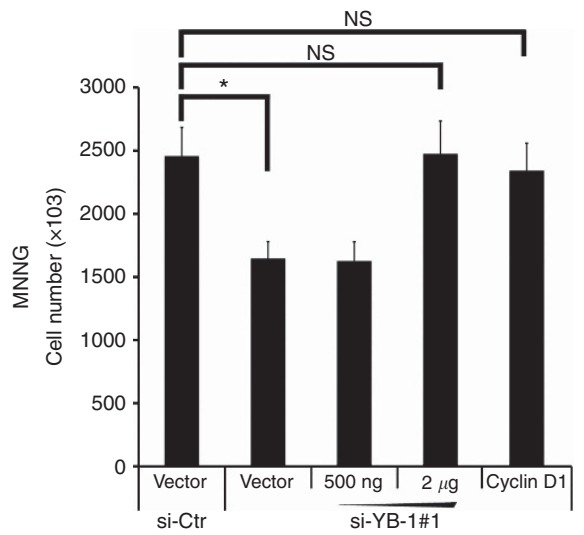

B

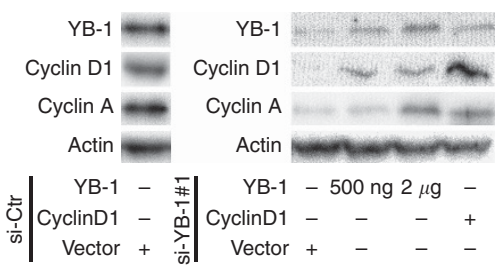

Figure 6. Effects of overexpression of YB-1 and cyclin D1 on si-YB-1-induced suppression of cell proliferation. (A) MG63 and MNNG cells were transfected with si-Ctr, si-YB-1\#1 (50 pmoll ${ }^{-1}$ ) and expression vectors of YB-1 (500 ng and $2 \mu \mathrm{g}$ ) and cyclin D1 for $48 \mathrm{~h}$. The cells were harvested with trypsin and counted. Experiments were performed in triplicate and data are expressed as the mean \pm s.d. ${ }^{\star} P<0.05$. (B) MG63 cells were transfected with si-Ctr, si-YB-1\#1 (50 pmol $\mathrm{I}^{-1}$ ) and expression vectors of YB-1 (500 ng and $2 \mu \mathrm{g}$ ) and cyclin D1 for $48 \mathrm{~h}$ and whole-cell extracts were subjected to SDS-PAGE, and western blot analysis was done with corresponding antibodies. Actin was used for internal normalisation. NS = nonsignificant

expression vectors of cyclin D1 and YB-1. Inhibition of cell proliferation by YB-1 knockdown was rescued by overexpression of YB-1 and cyclin D1 (Figure 6A). Western blot analysis confirmed that siRNA and expression plasmids properly in this experiments (Figure 6B). Importantly, overexpression of YB-1 and cyclin D1 induced the re-expression of cyclin A in si-YB-1\#1-treated cells shows (Figure 6B). Taken together, these results suggest that the primary reason for the G1/S phase growth arrest in YB-1 knockdown human OS cells was decreased expression of cyclin D1, followed by downregulation of cyclin A.
Knockdown of YB-1 inhibited the growth of OS graft tumours in vivo. We next investigated the therapeutic effectiveness of siYB-1 in vivo. We established a xenograft model of MNNG cells, as described in the Materials and Methods section. Tumour growth was examined by intratumoral treatment with si-YB-1 and atelocollagen, which increases cellular uptake and prolonged release of the siRNA without any serious side effects (Ochiya et al, 2001; Takei et al, 2004). After the tumours reached a volume of $65 \mathrm{~mm}^{3}$, the animals were randomly divided into two groups and si-YB-1 or scrambled si-Ctr was injected intratumorally at 
A

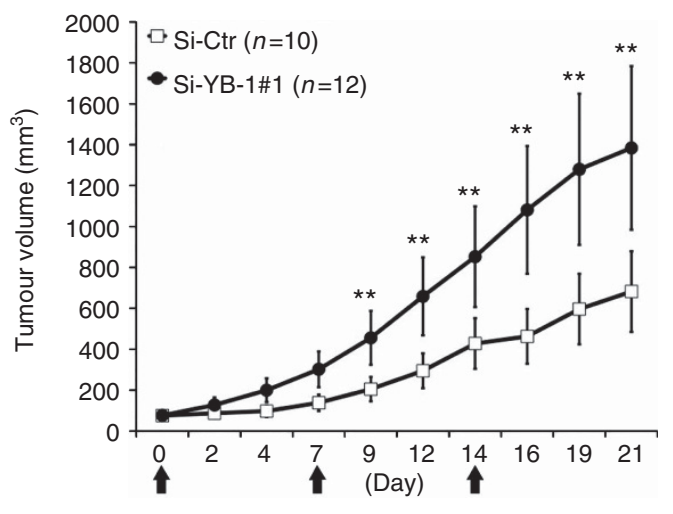

B

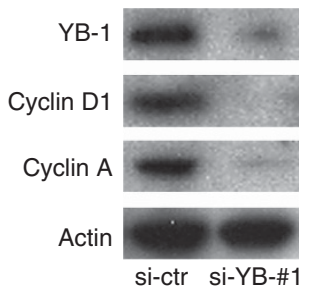

\section{E 70}

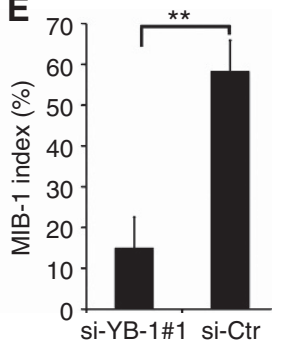

C
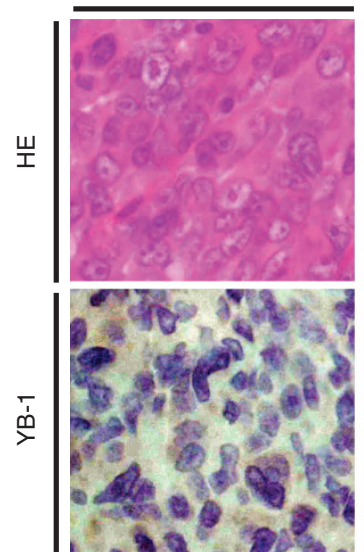

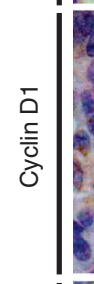
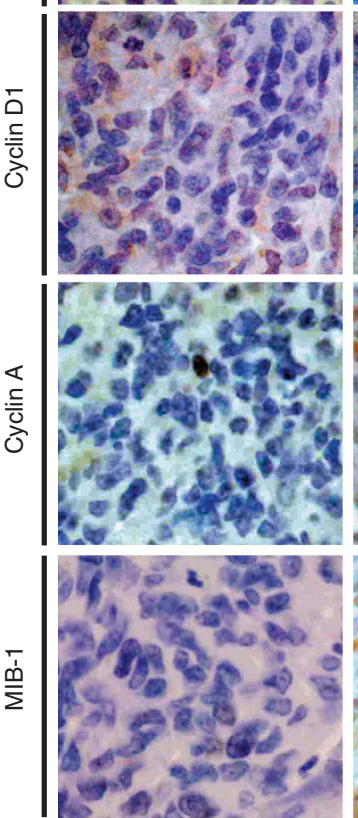
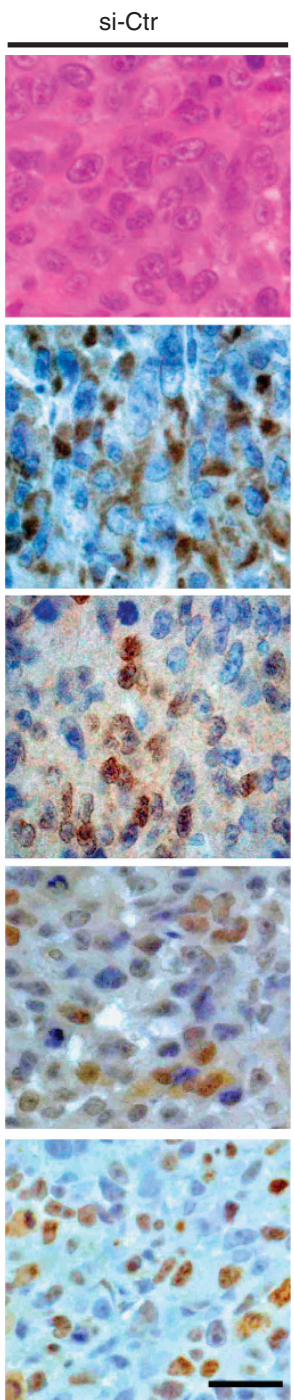

Figure 7. Inhibition of tumour growth by si-YB-1 with atelocollagen in the MNNG xenograft model. (A) Tumour growth curves after treatment with si-YB-1\#1 or si-Ctr with atelocollagen. Each therapeutic reagent was injected into the tumours on days 0, 7, and 14 (arrows). Data are expressed as the mean \pm s.d. ( $n=12$ for YB-1, $n=10$ for Ctr). ${ }^{\star \star} P<0.01$, when si-YB-1\#1 was compared with si-Ctr. (B) Levels of YB-1, cyclin D1, and cyclin $A$ in tumours were analysed by immunoblotting. Actin was used for internal normalisation. (C) Representative micrographs of haematoxylin - eosin staining and immunohistochemical detection of YB-1, cyclin D1, cyclin A, and MIB-1 in tumours treated with si-YB-1\#1(left) or si-Ctr (right). Scale bar; $20 \mu \mathrm{m}$ ( $\mathbf{D}$ and $\mathbf{E})$. The number of cells expressing YB-1 (D) and MIB-1 (E) was scored in five independent areas. The percentage of YB-1- or MIB-1-positive cells was then calculated. Data are expressed as the mean \pm s.d. ${ }^{* \star P} P<0.01$ si-YB-1\#1 vs si-Ctr.

days 0,7 , and 14 . No death, loss of body weight, or gross adverse effects occurred in the mice as a result of treatment with si-YB-1 or si-Ctr. The tumour growth was monitored over a period of up to 3 weeks. As shown in Figure 7A, si-YB-1\#1 suppressed tumour growth significantly in comparison with si-Ctr $(n=12$; si-YB-1: $682 \mathrm{~mm}^{3}$ vs $n=10$; si-Ctr: $\left.1384 \mathrm{~mm}^{3}, P=0.001\right)$. We have same results with alternative si-YB-1\#2 (Supplementary Figure 5). Furthermore, si-YB-1\#1 application decreased the expression of YB-1 in the tumours, confirmed by western blot analysis and immunohistochemistry (Figure $7 \mathrm{~B}$ and $\mathrm{C}$ ). The percentage of YB1 -positive cells was significantly reduced in tumours from mice treated with si-YB-1\#1 (si-YB-1, 25\%; si-Ctr, 91.7\%: $P=0.0035$ ), as shown in Figure 7D. We also examined the expression of MIB-1, an indicator of cell proliferation (Oda et al, 1998), by immunohistochemistry. As shown in Figure 7E, the percentage of MIB-1positive cells was significantly reduced in tumours from mice treated with si-YB-1\#1 (si-YB-1\#1, 15\%; si-Ctr, 58\%: $P=0.0035$ ). Remarkably, intratumoral injection of siYB-1\#1 also resulted in the loss of cyclin D1 and cyclin A expression (Figure 7B and C). Taken together, our data show that inhibition of YB-1 expression retarded tumour cell proliferation in vivo, partly due to reduced cyclin D1 and cyclin A expression.

Association of nuclear YB-1 expression and the clinical outcome of OS. We previously reported that nuclear expression of YB-1 is associated with expression of P-gp (Oda et al, 1998). Thus, we next examined whether nuclear expression of YB-1 in OS cells was associated with expression of cyclin D1 and cyclin A, and with clinical outcomes. Clinical characteristics at diagnosis are shown in Table 1. In the all OS tissue samples tested, tumour cells were positive for anti-YB-1 antibody in their cytoplasm, whereas nuclear expression of YB-1 was observed in 23 of 40 cases (57.5\%). We have same results with another antibody for YB-1 (EPITOMICS, Bulingame, CA, USA, 2387-1\#YF012911) (Supplementary Figure 6). Overexpression of cyclin D1 was detected in 24 of 40 patients (60\%), whereas overexpression of cyclin A was seen in 23 of 40 patients. Immunohistochemical images showing the presence (case 38) or absence/reduction (case 12) of nuclear YB-1, cyclin 
Table 1. Relationship between YB-1 nuclear expression and the clinicopathological characteristics of OS patients

\begin{tabular}{|l|c|c|}
\cline { 2 - 3 } \multicolumn{2}{c|}{} & \multicolumn{2}{c}{ YB-1 nuclear expression } \\
\hline Variable & Negative & Positive \\
\hline Sex & 9 & 15 \\
\hline Male & 8 & 8 \\
\hline Female & & \\
\hline
\end{tabular}

\section{Age, years}

\begin{tabular}{|l|l|l|}
\hline Range (median) & $7-58(19.88)$ & $9-53(19.78)$ \\
\hline
\end{tabular}

\section{Location}

Extremities

Trunk

18

Systemic multi-agent chemotherapy

\begin{tabular}{|l|c|c|}
\hline Yes & 17 & 23 \\
No & 0 & 0 \\
\hline
\end{tabular}

\section{Surgery and/or radiation}

\begin{tabular}{|l|c|c|}
\hline Yes & 17 & 21 \\
No & 0 & 0 \\
\hline
\end{tabular}

\section{Status}

Continuously disease free

No evidence of disease

Alive with disease

Dead of disease

Abbreviations: OS = osteosarcoma; YB-1 = Y-box binding protein-1.

D1, cyclin A, and MIB-1 are shown (Figure 8). Importantly, there was significant correlation between the nuclear expression of YB-1 and cyclin D1 and cyclin A in the nucleus of OS cells (Table 2).

Next, to investigate the prognostic significance of nuclear expression of YB-1, Kaplan-Meier survival analysis was performed. Significantly, nuclear expression of YB-1 was associated with poorer overall and event-free survival (log-lank test, $P=0.014$ in overall survival, $P=0.006$ in event-free survival; Figure 9). We also performed univariate and multivariate analyses, with the variables including nuclear expression of YB-1, cyclin D1, and cyclin A, the tumour site, age 16 years or younger, and MIB-1 expression. In the univariate analysis, only the nuclear expression of YB-1 was a significant predictor of poor prognosis, but the multivariate analysis revealed the nuclear expression of YB-1 was identified as significant factors (Table 3.)

\section{DISCUSSION}

Upregulation of YB-1 is observed in various solid tumours, and its expression level inversely correlates with cell proliferation (Shiota et al, 2008; Basaki et al, 2010). A recent study showed that nuclear YB-1 expression is induced during the G1-S transition of the cell cycle (Jurchott et al, 2003). Furthermore, alternations in G1/S is a critical factor contributing to oncogenesis in OS (Benassi et al, 1997), indicating that YB-1 could regulate the G1/S transition and proliferation of OS cells. We previously reported that the nuclear expression of YB-1 was closely associated with the expression of P-gp in OS cell lines (Oda et al, 1998). However, the cell proliferative roles of YB-1 in OS were unclear. To investigate this,
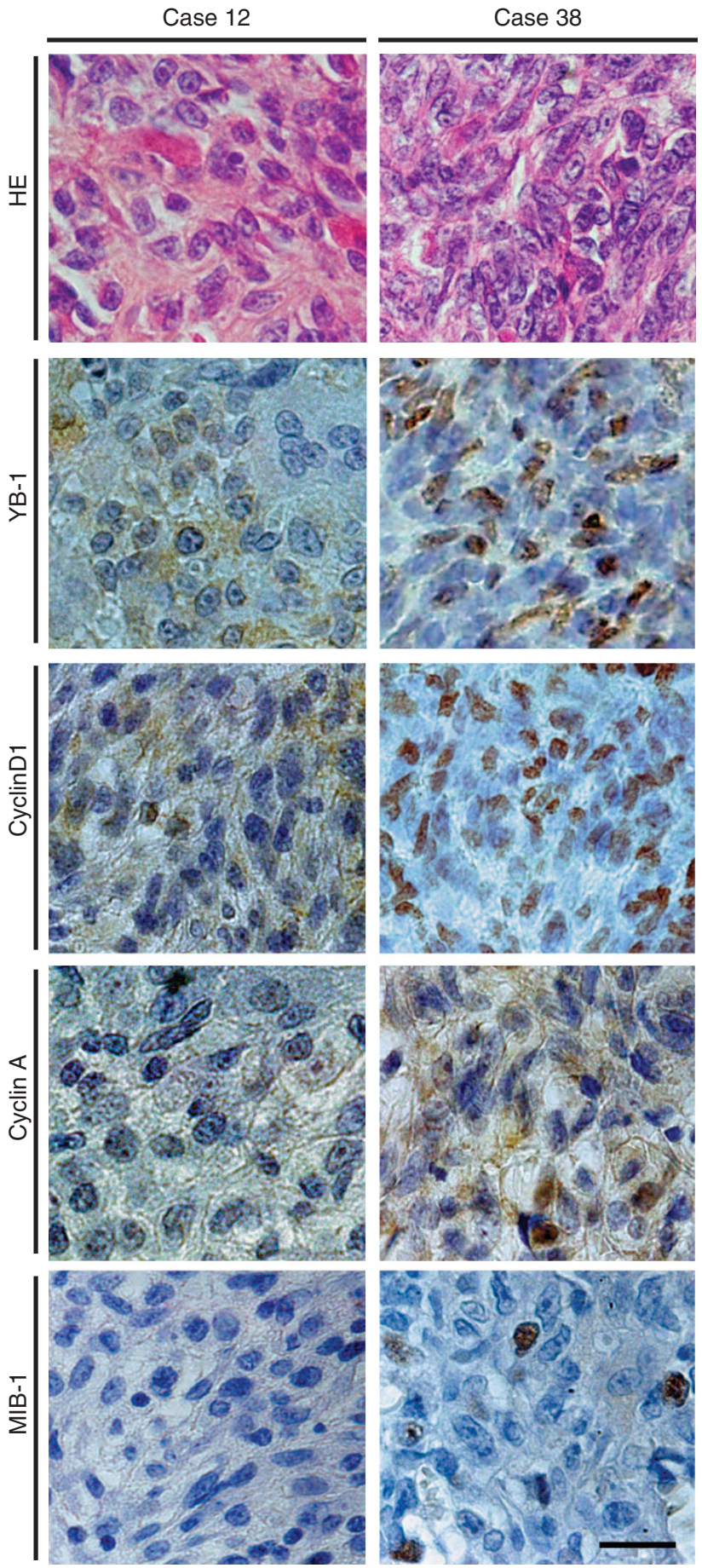

Figure 8. Haematoxylin - eosin and immunohistochemical staining of human OS sections. Representative staining of YB-1, cyclin D1, cyclin A, and MIB-1 in OS samples. Paraffin sections were stained with

haematoxylin - eosin and immunohistochemically stained using anti-YB1, anti-cyclin D1, anti-cyclin A, and anti-YB-1 antibodies, then were visualised using the diaminobenzidene substrate system.

Counterstaining was then performed using diluted haematoxylin. In case 38 (YB-1 nuclear expression positive, died of disease), high levels of cyclin D1 ( $\geqslant 10 \%)$ and cyclin $A(\geqslant 40 \%)$ expression were evident, whereas in case 12 (YB-1 nuclear expression negative, continuously disease free), expression of cyclin D1 and cyclin A were low. Scale bar, $20 \mu \mathrm{m}$.

we inhibited YB-1 using siRNA and found that reduction of YB-1 expression in OS cells resulted in decreased cell proliferation rates both in vitro and in a xenograft model of OS in nude mice. Moreover, nuclear expression of YB-1 was found to be closely 
Table 2. Correlation of the YB-1 nuclear expression with the expression of cyclin D1 and cyclin A

\begin{tabular}{|c|c|c|c|c|c|}
\hline \multirow{2}{*}{ Associated factor } & \multicolumn{5}{|c|}{ YB-1 nuclear expression } \\
\hline & Negative & Positive & OR & $95 \% \mathrm{Cl}$ & $P$-value \\
\hline \multicolumn{6}{|l|}{ Cyclin D1 } \\
\hline $\begin{array}{l}<10 \% \\
\geqslant 10 \%\end{array}$ & $\begin{array}{c}11 \\
6\end{array}$ & $\begin{array}{c}5 \\
18\end{array}$ & 6.6 & $1.62-26.9$ & 0.006 \\
\hline \multicolumn{6}{|l|}{ Cyclin A1 } \\
\hline $\begin{array}{l}<40 \% \\
\geqslant 40 \%\end{array}$ & $\begin{array}{c}12 \\
5\end{array}$ & $\begin{array}{c}5 \\
18\end{array}$ & 8.64 & $2.05-36.4$ & 0.002 \\
\hline $\begin{array}{l}\text { Abbreviations: } \mathrm{Cl}=\mathrm{co} \\
\text { Fisher's exact test }(P\end{array}$ & cee interval & $\mathrm{R}=$ odds & & $=Y$-box binc & protein-1 \\
\hline
\end{tabular}
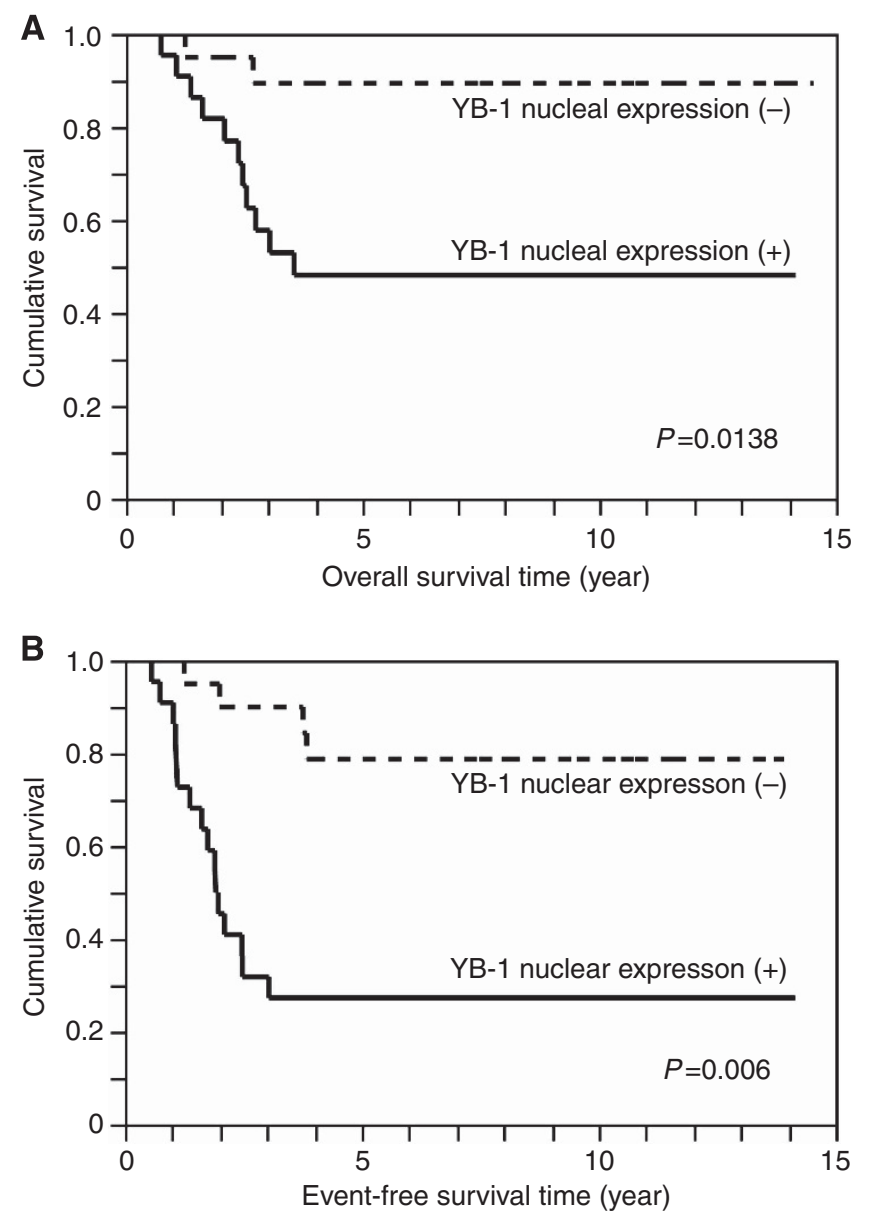

Figure 9. Association between YB-1 nuclear expression and poor prognosis in OS. Kaplan-Meier survival curves for all patients based on positive or negative YB-1 nuclear expression, overall survival (A) and event-free survival (B). Log-rank tests were performed to determine statistical significance, with $P<0.05$ defined as significant.

associated with proliferative activity, as evaluated by MIB-1-LI in our previous report (Oda et al, 1998). Together, these results indicate that $\mathrm{YB}-1$ has a role not only in acquisition of drug resistance, but also in the growth of OS cells.

In this study, we demonstrated that inhibition of YB-1 expression in OS cells resulted in a delayed G1/S transition, as observed in other tumours (Feng et al, 2009). The growth of eukaryotic cells, including tumour cells, is tightly regulated through a careful balance of positive and negative regulatory components
Table 3. The results of the univariate and multivariate analyses for overall survival

\begin{tabular}{|c|c|c|c|c|}
\hline & \multicolumn{2}{|c|}{ Univariate analysis } & \multicolumn{2}{|c|}{ Multivariate analysis } \\
\hline Variable & Hazard ratio & $P$-value & Hazard ratio & $\boldsymbol{P}$-value \\
\hline \multicolumn{5}{|c|}{ YB-1 nuclear expression } \\
\hline $\begin{array}{l}\text { Negative } \\
\text { Positive }\end{array}$ & $\begin{array}{l}0.1860 \\
1\end{array}$ & 0.0090 & $\begin{array}{l}0.1946 \\
1\end{array}$ & 0.0420 \\
\hline \multicolumn{5}{|l|}{ Cyclin D1 } \\
\hline $\begin{array}{l}<10 \% \\
\geqslant 10 \%\end{array}$ & $\begin{array}{l}0.9242 \\
1\end{array}$ & 0.8844 & $\begin{array}{l}0.4718 \\
1\end{array}$ & 0.2473 \\
\hline \multicolumn{5}{|l|}{ Cyclin A } \\
\hline $\begin{array}{l}<40 \% \\
\geqslant 40 \%\end{array}$ & $\begin{array}{l}0.3077 \\
1\end{array}$ & 0.0483 & $\begin{array}{l}0.4814 \\
1\end{array}$ & 0.4134 \\
\hline \multicolumn{5}{|c|}{ Tumour location } \\
\hline $\begin{array}{l}\text { Extremities } \\
\text { Trunk }\end{array}$ & $\begin{array}{l}0.6057 \\
1\end{array}$ & 0.5385 & $\begin{array}{l}0.8155 \\
1\end{array}$ & 0.8342 \\
\hline \multicolumn{5}{|c|}{ Age, years } \\
\hline $\begin{array}{l}<16 \\
\geqslant 16\end{array}$ & $\begin{array}{l}0.7271 \\
1\end{array}$ & 0.6794 & $\begin{array}{l}0.9583 \\
1\end{array}$ & 0.8080 \\
\hline \multicolumn{5}{|l|}{ MIB-1 } \\
\hline $\begin{array}{l}<10 \% \\
\geqslant 10 \%\end{array}$ & $\begin{array}{l}2.6766 \\
1 \\
\end{array}$ & 0.1511 & $\begin{array}{l}0.3813 \\
1 \\
\end{array}$ & 0.2020 \\
\hline
\end{tabular}

that regulate the G1 phase of the cell cycle (Hunter and Pines, 1994; Sherr, 1993), such as cyclin D1, cyclin E, and cyclin A. In particular, the G1/S transition is mainly regulated by G1 cyclins, including cyclin D1, cyclin E, and cyclin A. G1 cyclins bind to respective CDKs and facilitate cell cycle progression from the G1 phase to the $S$ phase. On the contrary, two mammalian gene families of cyclin kinase inhibitors (CKIs) have been identified: one family includes p16, p15, and p18 and the other includes p21, p27, and p57. These CKIs co-ordinately keep the retinoblastoma protein in its active and hypophosphorylated form, and causes G0/G1 arrest (Matsumoto et al, 2001). Thus, we investigated that G1 cyclins might be regulated by YB-1 in OS cells. Among the G1 cyclins, cyclin A has been reported to contain Y-box sequences in its promoter/enhancer regions (Jurchott et al, 2003), indicating that cyclin A might be a direct target of YB-1 in OS cells. However, inhibition of YB-1 in OS cells did not affect the expression level of cyclin A mRNA. In contrast, inhibition of YB-1 in OS cells resulted in reduced cyclin D1 mRNA expression and loss of cyclin D1 protein. Intriguingly, we found that the promoter region of the cyclin D1 gene contains at least four Y-box sequences, suggesting that YB-1 may directly regulate the transcription of cyclin D1 in OS cells. To confirm this notion, we performed ChIP and have clearly shown that YB-1 is a potential and direct transcriptional regulator of cyclin D1 in OS cell lines. Notably, recent study has also shown that, in breast cancer cells, YB-1 binds to the promoter of cyclin D1, strongly supporting our results (Lasham et al, 2012).

Interestingly, a positive, statistically significant correlation was found between cyclin A and MIB-1 expression in OS cells (Molendini et al, 1998). Furthermore, cyclin A mutation acts as a critical genetic event in the c-Fos-induced transformation of osteoblasts (Sunters et al, 2004). However, the role of cyclin A in the proliferation of OS cells remains unclear. Of note, the cyclin A protein was recently shown to be regulated at multiple 
post-transcriptional steps through translational and proteolytic control (Vardy et al, 2009). In addition, YB-1 has been shown to have a role in mRNA translational regulation (Evdokimova et al, 2006), suggesting that YB-1 might maintain the post-transcriptional regulation of cyclin $\mathrm{A}$ in OS cells. Thus, inhibition of YB-1 would result in reduced cyclin A protein expression, without affecting the cyclin A mRNA levels. However, this hypothesis should be further investigated through in vitro analyses. To explore this, we inhibited the expression of cyclin $\mathrm{A}$ in OS cells and demonstrated that cyclin A is indispensable for the G1/S transition and proliferation of OS cells. Notably, the expression level of cyclin A was clearly correlated with nuclear YB-1 expression. In addition, the expression level of cyclin A was correlated with overall survival of OS patients in this study (data not shown), further supporting the notion that cyclin A is a downstream, indirect target of YB-1 in the cell cycle control of OS cells.

Small interfering RNA has been used widely as an experimental tool to analyse the molecular mechanisms leading to uncontrolled cell proliferation in malignant tumours (Takeshita and Ochiya, 2006). To develop siRNAs for malignant tumour therapy, a reliable and efficient delivery system is essential for effective treatment. Atelocollagen is already used clinically for a wide range of purposes, such as a bone cartilage substitute and a haemostatic agent, indicating that atelocollagen is innocuous in vivo (Ochiya et al, 2001). Furthermore, it is known that atelocollagen complexed with siRNA is resistant to nucleases and is efficiently transduced into cells, thereby extending the half-life of siRNAs in vivo. (Minakuchi et al, 2004). Remarkably, siRNA with atelocollagen in xenograft tumours in mice remains intact for at least a week (Takei et al, 2004). In this study, we injected si-YB-1 into the xenograft of OS cells once a week, and found that si-YB-1 inhibited YB-1 expression and dramatically suppressed tumour proliferation. Bone and soft tissue tumours, including OS, tend to present on the limbs; thus, local administration of siRNA with atelocollagen will be easy to apply. We believe that targeting YB-1 with siRNA and atelocollagen could be a novel and effective treatment against OS. However, local administration of siRNA into bone tumours, including OS, is not feasible. Interestingly, an atelocollagen complex can be delivered intravenously as nanoparticles, making systemic delivery of siRNA possible. A recent report showed the potential for atelocollagenmediated systemic antisense therapeutics in a mouse model of bone metastasis without any side effects. Therefore, we believe that targeting YB-1 with siRNA and atelocollagen could be a novel and effective treatment for OS (Takeshita et al, 2005).

We previously found that nuclear expression of YB-1 is closely associated with P-gp expression in human OS samples (Oda et al, 1998). However, controversy still surrounds whether P-gp is a prognostic factor for the response to chemotherapy and clinical prognosis in patients with OS (Pakos and Ioannidis, 2003). To date, several molecules, including p53 (Pápai et al, 1997), ErbB2 (Akatsuka et al, 2002), and heat shock protein (Uozaki et al,1997), have proposed as prognostic biomarkers for OS. In this study, we clearly demonstrated that YB-1 nuclear expression is positively associated with poor prognosis in patients with OS. Importantly, this nuclear expression of YB-1 was also correlated with expression of cyclin D1 and cyclin A, further supporting the notion that YB-1 enhances the proliferation of OS cells by regulating the G1/S transition. Thus, we believe that YB-1 is a potentially clinically useful biomarker of proliferation in OS, and a promising molecular target for developing novel OS therapeutic agents.

\section{ACKNOWLEDGEMENTS}

We thank Dr Masaki Shiota for technical advice and Dr Junji Kishimoto for helpful suggestions on statistics. This work was supported by a Grant-in-Aid for Scientific Research from the Japan Society for the Promotion of Science, and a Grant-in-Aid for Clinical Research Evidence-Based Medicine and Cancer Research from the Ministry of Health, Labour and Welfare of Japan (\#19390397 and \#23592192).

\section{REFERENCES}

Akatsuka T, Wada T, Kokai Y, Kawaguchi S, Isu K, Yamashiro K, Yamashita T, Sawada N, Yamawaki S, Ishii S (2002) ErbB2 expression is correlated with increased survival of patients with osteosarcoma. Cancer 94: 1397-1404.

Asakuno K, Kohno K, Uchiumi T, Kubo T, Sato S, Isono M, Kuwano M (1994) Involvement of a DNA binding protein, MDR-NF1/YB-1, in human MDR1 gene expression by actinomycin D. Biochem Biophys Res Commun 199: 1428-1435.

Bargou RC, Jürchott K, Wagener C, Bergmann S, Metzner S, Bommert K, Mapara MY, Winzer KJ, Dietel M, Dörken B, Royer HD (1997) Nuclear localization and increased levels of transcription factor YB-1 in primary human breast cancers are associated with intrinsic MDR1 gene expression. Nat Med 3: 447-450.

Basaki Y, Taguchi K, Izumi H, Murakami Y, Kubo T, Hosoi F, Watari K, Nakano K, Kawaguchi H, Ohno S, Kohno K, Ono M, Kuwano M (2010) Y-box binding protein-1 (YB-1) promotes cell cycle progression through CDC6-dependent pathway in human cancer cells. Eur J Cancer 46: 954-965.

Benassi MS, Molendini L, Gamberi G, Sollazzo MR, Ragazzini P, Merli M, Magagnoli G, Sangiorgi L, Bacchini P, Bertoni F, Picci P (1997) Altered G1 phase regulation in osteosarcoma. Int J Cancer 74: 518-522.

Bergmann S, Royer-Pokora B, Fietze E, Jürchott K, Hildebrandt B, Trost D, Leenders F, Claude JC, Theuring F, Bargou R, Dietel M, Royer HD (2005) YB-1 provokes breast cancer through the induction of chromosomal instability that emerges from mitotic failure and centrosome amplification. Cancer Res 65: 4078-4087.

Chandar N, Billig B, McMaster J, Novak J (1992) Inactivation of p53 gene in human and murine osteosarcoma cells. Br J Cancer 65: 208-214.

Chatterjee M, Rancso C, Stühmer T, Eckstein N, Andrulis M, Gerecke C, Lorentz H, Royer HD, Bargou RC (2008) The Y-box binding protein YB-1 is associated with progressive disease and mediates survival and drug resistance in multiple myeloma. Blood 111: 3714-3722.

Das S, Chattopadhyay R, Bhakat KK, Boldogh I, Kohno K, Prasad R, Wilson SH, Hazra TK (2007) Stimulation of NEIL2-mediated oxidized base excision repair via YB-1 interaction during oxidative stress. J Biol Chem 282: 28474-28484.

Evdokimova V, Ovchinnikov LP, Sorensen PH (2006) Y-box binding protein 1: providing a new angle on translational regulation. Cell Cycle 5: 1143.

Feng Q, Huang S, Zhang A, Chen Q, Guo X, Chen R, Yang T (2009) Y-box protein 1 stimulates mesangial cell proliferation via activation of ERK1/2. Nephron Exp Nephrol 113: e16-e25.

Fujiwara T, Fukushi J, Yamamoto S, Matsumoto Y, Setsu N, Oda Y, Yamada H, Okada S, Watari K, Ono M, Kuwano M, Kamura S, Iida K, Okada Y, Koga M, Iwamoto Y (2011) Macrophage infiltration predicts a poor prognosis for human ewing sarcoma. Am J Pathol 179: 1157-1170.

Ganjavi H, Gee M, Narendran A, Parkinson N, Krishnamoorthy M, Freedman MH, Malkin D (2006) Adenovirus-mediated p53 gene therapy in osteosarcoma cell lines: sensitization to cisplatin and doxorubicin. Cancer Gene Ther 13: 415-419.

Giménez-Bonafé P, Fedoruk MN, Whitmore TG, Akbari M, Ralph JL, Ettinger S, Gleave ME, Nelson CC (2004) YB-1 is upregulated during prostate cancer tumor progression and increases P-glycoprotein activity. Prostate 59: 337-349.

Hanai K, Takeshita F, Honma K, Nagahara S, Maeda M, Minakuchi Y, Sano A, Ochiya T (2006) Atelocollagen-mediated systemic DDS for nucleic acid medicines. Ann N Y Acad Sci 1082: 9-17.

Homer C, Knight DA, Hananeia L, Sheard P, Risk J, Lasham A, Royds JA, Braithwaite AW (2005) Y-box factor YB1 controls p53 apoptotic function. Oncogene 24: 8314-8325.

Honma K, Ochiya T, Nagahara S, Sano A, Yamamoto H, Hirai K, Aso Y, Terada M (2001) Atelocollagen-based gene transfer in cells allows highthroughput screening of gene functions. Biochem Biophys Res Commun 289: 1075-1081. 
Huang SF, Cheng SD, Chuang WY, Chen IH, Liao CT, Wang HM, Hsieh LL (2012) Cyclin D1 overexpression and poor clinical outcomes in Taiwanese oral cavity squamous cell carcinoma. World J Surg Oncol 10: 40.

Hunter T, Pines J (1994) Cyclins and cancer. II: cyclin D and CDK inhibitors come of age. Cell 79: 573-582.

Iwamoto Y, Tanaka K, Isu K, Kawai A, Tatezaki S, Ishii T, Kushida K, Beppu Y, Usui M, Tateishi A, Furuse K, Minamizaki T, Kawaguchi N, Yamawaki S (2009) Multiinstitutional phase II study of neoadjuvant chemotherapy for osteosarcoma (NECO study) in Japan: NECO-93J and NECO-95J. J Orthop Sci 14: 397-404.

Jurchott K, Bergmann S, Stein U, Walther W, Janz M, Manni I, Piaggio G, Fietze E, Dietel M, Royer HD (2003) YB-1 as a cell cycle-regulated transcription factor facilitating cyclin A and cyclin B1 gene expression. $J$ Biol Chem 278: 27988-27996.

Kamura S, Matsumoto Y, Fukushi JI, Fujiwara T, Iida K, Okada Y, Iwamoto Y (2010) Basic fibroblast growth factor in the bone microenvironment enhances cell motility and invasion of Ewing's sarcoma family of tumours by activating the FGFR1-PI3K-Rac1 pathway. Br J Cancer 103: 370-381.

Kohno K, Izumi H, Uchiumi T, Ashizuka M, Kuwano M (2003) The pleiotropic functions of the Y-box-binding protein, YB-1. Bioessays 25: 691-698.

Ladomery M (1997) Multifunctional proteins suggest connections between transcriptional and post-transcriptional processes. Bioessays 19: 903-909.

Lasham A, Samuel W, Cao H, Patel R, Mehta R, Stern JL, Reid G, Woolley AG, Miller LD, Black MA, Shelling AN, Print CG, Braithwaite AW (2012) YB-1, the E2F pathway, and regulation of tumor cell growth. J Natl Cancer Inst 104: 133-146.

Law WJ, Cann KL, Hicks GG (2006) TLS, EWS and TAF15: a model for transcriptional integration of gene expression. Brief Funct Genomic Proteomic 5: 8-14.

Lee C, Dhillon J, Wang MY, Gao Y, Hu K, Park E, Astanehe A, Hung MC, Eirew P, Eaves CJ, Dunn SE (2008) Targeting YB-1 in HER-2 overexpressing breast cancer cells induces apoptosis via the mTOR/ STAT3 pathway and suppresses tumor growth in mice. Cancer Res 68 : 8661-8666.

Lu ZH, Books JT, Ley TJ (2005) YB-1 is important for late-stage embryonic development, optimal cellular stress responses, and the prevention of premature senescence. Mol Cell Biol 25: 4625-4637.

Matsumoto K, Wolffe AP (1998) Gene regulation by Y-box proteins: coupling control of transcription and translation. Trends Cell Biol 8: 318-323.

Matsumoto Y, Tanaka K, Nakatani F, Matsunobu T, Matsuda S, Iwamoto Y (2001) Downregulation and forced expression of EWS-Flil fusion gene results in changes in the expression of $\mathrm{G}(1)$ regulatory genes. Br J Cancer 84: 768-775.

Minakuchi Y, Takeshita F, Kosaka N, Sasaki H, Yamamoto Y, Kouno M, Honma K, Nagahara S, Hanai K, Sano A, Kato T, Terada M, Ochiya T (2004) Atelocollagen-mediated synthetic small interfering RNA delivery for effective gene silencing in vitro and in vivo. Nucleic Acids Res 32: e109.

Molendini L, Benassi MS, Magagnoli G, Merli M, Sollazzo MR, Ragazzini P, Gamberi G, Ferrari C, Balladelli A, Bacchini P, Picci P (1998) Prognostic significance of cyclin expression in human osteosarcoma. Int J Oncol 12: 1007-1011.

Ochiya T, Nagahara S, Sano A, Itoh H, Terada M (2001) Biomaterials for gene delivery: atelocollagen-mediated controlled release of molecular medicines. Curr Gene Ther 1: 31-52.

Oda Y, Sakamoto A, Shinohara N, Ohga T, Uchiumi T, Kohno K, Tsuneyoshi M, Kuwano M, Iwamoto Y (1998) Nuclear expression of YB-1 protein correlates with P-glycoprotein expression in human osteosarcoma. Clin Cancer Res 4: 2273-2277.

Ohga T, Koike K, Ono M, Makino Y, Itagaki Y, Tanimoto M, Kuwano M, Kohno K (1996) Role of the human Y box-binding protein YB-1 in cellular sensitivity to the DNA-damaging agents cisplatin, mitomycin C, and ultraviolet light. Cancer Res 56: 4224-4228.
Pakos EE, Ioannidis JP (2003) The association of P-glycoprotein with response to chemotherapy and clinical outcome in patients with osteosarcoma. A meta-analysis. Cancer 98: 581-589.

Pápai Z, Féja CN, Hanna EN, Sztán M, Oláh E, Szendrôi M (1997) P53 Overexpression as an indicator of overall survival and response to treatment in osteosarcomas. Pathol Oncol Res 3: 15-19.

Schittek B, Psenner K, Sauer B, Meier F, Iftner T, Garbe C (2007) The increased expression of $\mathrm{Y}$ box-binding protein 1 in melanoma stimulates proliferation and tumor invasion, antagonizes apoptosis and enhances chemoresistance. Int J Cancer 120: 2110-2118.

Sherr CJ (1993) Mammalian G1 cyclins. Cell 73: 1059-1065.

Shibao K, Takano H, Nakayama Y, Okazaki K, Nagata N, Izumi H, Uchiumi T, Kuwano M, Kohno K, Itoh H (1999) Enhanced coexpression of YB-1 and DNA topoisomerase II alpha genes in human colorectal carcinomas. Int J Cancer 83: 732-737.

Shiota M, Izumi H, Onitsuka T, Miyamoto N, Kashiwagi E, Kidani A, Yokomizo A, Naito S, Kohno K (2008) Twist promotes tumor cell growth through YB-1 expression. Cancer Res 68: 98-105.

Simbulan-Rosenthal CM, Rosenthal DS, Iyer S, Boulares AH, Smulson ME (1998) Transient poly(ADP-ribosyl)ation of nuclear proteins and role of poly(ADP-ribose) polymerase in the early stages of apoptosis. J Biol Chem 273: $13703-13712$.

Sunters A, Thomas DP, Yeudall WA, Grigoriadis AE (2004) Accelerated cell cycle progression in osteoblasts overexpressing the $\mathrm{c}$-fos proto-oncogene: induction of cyclin A and enhanced CDK2 activity. J Biol Chem 279: 9882-9891.

Takei Y, Kadomatsu K, Yuzawa Y, Matsuo S, Muramatsu T (2004) A small interfering RNA targeting vascular endothelial growth factor as cancer therapeutics. Cancer Res 64: 3365-3370.

Takeshita F, Minakuchi Y, Nagahara S, Honma K, Sasaki H, Hirai K, Teratani T, Namatame N, Yamamoto Y, Hanai K, Kato T, Sano A, Ochiya T (2005) Efficient delivery of small interfering RNA to bone-metastatic tumors by using atelocollagen in vivo. Proc Natl Acad Sci USA 102: 12177-12182.

Takeshita F, Ochiya T (2006) Therapeutic potential of RNA interference against cancer. Cancer Sci 97: 689-696.

Takigami I, Ohno T, Kitade Y, Hara A, Nagano A, Kawai G, Saitou M, Matsuhashi A, Yamada K, Shimizu K (2011) Synthetic siRNA targeting the breakpoint of EWS/Fli-1 inhibits growth of Ewing sarcoma xenografts in a mouse model. Int J Cancer 128: 216-226.

Trock BJ, Leonessa F, Clarke R (1997) Multidrug resistance in breast cancer: a meta-analysis of MDR1/gp170 expression and its possible functional significance. J Natl Cancer Inst 89: 917-931.

Uchiumi T, Fotovati A, Sasaguri T, Shibahara K, Shimada T, Fukuda T, Nakamura T, Izumi H, Tsuzuki T, Kuwano M, Kohno K (2006) YB-1 is important for an early stage embryonic development: neural tube formation and cell proliferation. J Biol Chem 281: 40440-40449.

Uozaki H, Horiuchi H, Ishida T, Iijima T, Imamura T, Machinami R (1997) Overexpression of resistance-related proteins (metallothioneins, glutathione-S-transferase pi, heat shock protein 27 , and lung resistancerelated protein) in osteosarcoma. Relationship with poor prognosis. Cancer 79: 2336-2344.

Vardy L, Pesin JA, Orr-Weaver TL (2009) Regulation of cyclin A protein in meiosis and early embryogenesis. Proc Natl Acad Sci USA 106: 1838-1843.

Weinberg RA (1989) Oncogenes, antioncogenes, and the molecular bases of multistep carcinogenesis. Cancer Res 49: 3713-3721.

This work is published under the standard license to publish agreement. After 12 months the work will become freely available and the license terms will switch to a Creative Commons AttributionNonCommercial-Share Alike 3.0 Unported License.

Supplementary Information accompanies this paper on British Journal of Cancer website (http://www.nature.com/bjc) 